\title{
Intellectual Capital Utilization And Intellectual Capital Growth In Improving Current And Future Financial Performance In Asean In The Era Of Asean Economic Community
}

\author{
Bima Cinintya Pratama ${ }^{1)}$, Hardiyanto Wibowo ${ }^{2)}$, Maulida Nurul Innayah ${ }^{3)}$, Fatmah Bagis ${ }^{4)}$ \\ 1,2,3,4 Universitas Muhammadiyah Purwokerto \\ *Email korespondensi: pratamabima@gmail.com
}

\begin{abstract}
This paper examines the association between intellectual capital (IC), rate of growth of intellectual capital (ROGIC), and firm financial performance in an emerging market context, which is ASEAN. The effect of Intellectual Capital and the rate of growth of Intellectual capital is tested towards firm financial performance, namely current financial performance and future financial performance. Panel data regression model analysis is used for a sample of manufacturing companies in ASEAN countries, namely Indonesia, Malaysia, Philippines, Thailand, and Singapore during 2015-2018. The results showed that intellectual capital and ROGIC has a positive effect on firm financial performance, both current and future performance. This result indicates that intellectual capital can generate higher financial performance for the firms, both in the current period and until the future period. A similar result also found in the relationship between ROGIC which is the rate of growth of IC toward firm financial performance. This result implies that firms should utilize and maintain intellectual capital together with maintaining IC growth (ROGIC) to maintain and preserve its performance in the current and future term.
\end{abstract}

Keywords: Intellectual Capital, Rate of Growth of Intellectual Capital, Firm Financial Performance.

Citation suggestions: Pratama, B. C., Wibowo, H., Innayah, M. N., \& Bagis, F. (2020). Intellectual Capital Utilization And Intellectual Capital Growth In Improving Current And Future Financial Performance In Asean In The Era Of Asean Economic Community. Jurnal Akuntansi dan Pajak, 21 (1), 103-111. doi:http://dx.doi.org/10.29040/jap.v21i1.1076

\section{DOI: $\underline{\text { http://dx.doi.org/10.29040/jap.v21i1.1076 }}$}

\section{INTRODUCTION}

In this era of globalization, more and more companies in the world are doing business operations outside the boundaries of the country. This demonstrates the direction of global business operations. Globalization also leads to the emergence of many multinational companies that allow capital switching. In the era of globalization, financial markets are growing, one of which is characterized by the existence of several national companies that get funding from the foreign capital market. Besides, globalization in the economic field is also demonstrated with the increasing number of international community cooperation conducted by several countries, including in the ASEAN region with the ASEAN Economic Community (MEA) which came into effect at the end of the year 2015.

The enactment of the ASEAN Economic Community (MEA) can provide a positive impact on economic growth in the ASEAN region. Meanwhile, not close the possibility of competition between companies and organizations in the ASEAN region that will become increasingly competitive. This will certainly require the company to improve and improve its performance through the use of more effective and efficient resources so that the company can create value-added and compete in competitive markets.

According to resource-based theory, intellectual capital (hereinafter called IC) is a resource that is at the core of the creation of value and the company's competitive advantage (Barney, 1991). Chen et al. (2005) and Wang (2008) explained that with the sustained competitive advantage of IC, the company will win a competition with other companies so that they can create value and bring success. In previous research, there have been several studies trying to test the relationship between IC and company 
performance, but the results are still not consistent. The research of Firer and Stainbank (2003), Chen et al. (2005), Tan et al. (2007), Clarke et al. (2011), Pratama (2016), and Pratama and Wibowo (2017) managed to find evidence that IC was positively related to the company's performance. Meanwhile, research from Firer and Williams (2003), Chan (2009), and Maditinos et al. (2011) did not manage to find evidence of the relationship between IC and Proxy.

The positive influence of intellectual capital not only impacts the company's current financial performance but also future financial performance. Tan, et al. (2007) argues that if IC is the main driver of the value of the company, then logically IC is also correlated with future performance enhancement, not only in today's performance. Intellectual capital utilization will maximize the effectiveness and efficiency of the company. Investor confidence will be increasingly higher if the company continues to explore and exploit the IC as best as possible. The company will continue to maintain and even improve its financial performance in the present and future so that investors will have confidence in the company not only at this time but also in the future (Astuti and Margasari, 2016). Previous research (Tan, et al., 2007; Astuti and Margasari, 2016; Nuraini, et al., 2018) succeeded in proving IC's influence on the company's future financial performance.

If IC is a major driver for the value of the company, then the company that has the higher IC will be more likely to have a better future performance, then the logic, IC growth rate (ROGIC) will also have a positive effect on the company's future performance (Tan et al., 2007). In the study of Tan et al. (2007), It proved that ROGIC had a positive influence on the company's future performance. Therefore, the third goal of the study was to test the positive influence of ROGIC against current and future financial performance.

The study uses monetary measurements, which are value-added intellectual coefficient (VAIC) developed by Pulic $(2000,2004)$ as IC meters. This research was conducted on companies engaged in manufacturing industries located in ASEAN countries, such as Indonesia, Malaysia, Singapore, Thailand, and the Philippines. The manufacturing industry is chosen because it is an industry that relies on IC for its corporate activities and innovations. The research uses a regression model of the data panel, i.e. fixed effect and random effect regression. This research contributes by providing practical implications to the company to maximize the utilization of IC and IC growth to improve the company's financial performance, both in the present and future.

\section{a. Resource-based theory (RBT)}

RBT provides an important framework for explaining and predicting what underlies the competitive edge and performance of the company (Barney et al., 2011). RBT explains that the creation of sustainable competitive advantages relates very closely to the company's ability to maintain valuable, scarce, and indispensable resource assets and allocate and disseminate such resources effectively (Barney, 1991).

Kozlenkova et al. (2014) Explain that the fundamental logic of this theory is based on two fundamental assumptions regarding the company's resources that explain how those resources are generating a sustainable competitive edge and explain why some companies can consistently perform better than any other company. First, the company has a set of different resources, although it is within the same industry (Peteraf and Barney, 2003). Assumptions regarding this heterogeneity of resources indicate that some companies have more expertise in completing certain activities because they have unique resources (PETERAF and Barney, 2003). Secondly, the differences in the resources will still exist due to the difficulty of exchanging resources between companies (resource immobility assumption), which will cause the benefit of the existence of this resource heterogeneity continues to occur also from time to time.

Characteristic Valuable, Rare, imperfectly imitable, Organization (VRIO) shows four conditions to assess how much potential a resource is to produce a sustained competitive advantage (Kozlenkova et al., 2014). The four characteristics of VRIO are as follows:

1) Valuable

Enterprise resources can be said to be valuable when these resources allow companies to develop and implement strategies that can lower company costs and/or increase company revenue more than when such resources do not exist.

2) Rare 
Scarce resources are resources that are only controlled by a small number of competing companies. If the resource is valuable but not rare, then exporting it will produce competitive equality, because other companies that have the resources also have the ability to exploit.

3) Imperfectly imitable

Resources that imperfectly imitable cannot be obtained through duplication or direct substitution by companies that do not have them.

4) Organization

The company's resources should be able to be organized for maximum competitive potential. The organization acts as a customizer factor that enables or prevents the company to fully realize the benefits contained in those valuable, scarce, and costly resources to emulate.

Based on the explanation above, according to RBT, IC has a big potential to fulfill the VRIO criteria above so it can create a competitive advantage for the company. With a competitive advantage, it can be used by companies to compete in competitive markets and achieve optimal performance.

\section{b. Intellectual Capital}

Intellectual Capital is a collection of intangible assets or intangible resources owned and used by companies to create value and competitive advantage of the company (Nahapiet and Ghoshal, 1998). Some researchers have different explanations about this IC, one of which is Bontis (1996) which explains that IC is difficult to understand, but when it is found and exploited can provide a new resource company that can provide strength for the company to compete and win the competition. Meanwhile, Sullivan and Sullivan (2000) stated that IC is a knowledge that can be converted into profit, in which not only the knowledge and skills of employees but also including the company's infrastructure, customer relations, information systems, technology, and the ability to innovate and create. Based on these explanations, it can be concluded that IC plays an important role in the creation of value and sustainability of the company's growth. Pulic $(2000,2004)$ presents a model for measuring IC, which is VAIC (Value added intellectual coefficient). The VAIC method outlines the three main components of intellectual capital:

1) Human capital
Human Capital in a company is the sum of competence, knowledge, expertise, innovation skills, attitudes, commitments, wisdom, and experience that is owned by employees in a company. This capital represents the knowledge capital of individuals in an organization to achieve a certain target (Seleim et al., 2007; Cabello-Medina et al., 2011; Campbell et al., 2012).

2) Structural capital dan Relational capital

Structural Capital is an intangible asset that remains within the company that gives employees the ability to fulfill the company's routine process and its structure that supports employees ' efforts to produce optimal intellectual performance and overall business performance. Structural Capital is embedded in the organization and can be described as valuable strategic assets, such as organizational capabilities, organizational culture, routines, procedures, information systems, hardware, software, databases, corporate image, patents, copyrights, trademarks, and so forth (Aramburu and Saenz, 2011; Zangoueinezhad and Moshabaki, 2009). In the meantime, Relational capital refers to the knowledge and learning skills that exist in the relationship between an organization and external stakeholders (Bontis, 1998; Kale et al., 2000). This is important to the organization as it can help create organizational value by linking internal intellectual resources to external stakeholders (Carmeli and Azeroual, 2009; Kong and Farrell, 2010).

3) Capital Employed

Capital employed is interpreted as physical capital and financial asset owned by the company to conduct operational activities of the company (Chen et al., 2005). Pulic (2000) explained that capital employed is important to be included in IC measurement models because the main purpose of each business is clear to create as many value-added from each physical, financial, and intellectual capital owned by the business.

c. Research Hypothesis Development

1) Intellectual Capital dan Current Company Performance 
IC plays an important role in the creation of value and sustainability of company growth. It is in line with the resource-based theory (RBT), which explains that IC is the core of value creation and the company's competitive Edge (Barney, 1991). From the perspective of RBT, the creation of a sustainable competitive advantage relates very closely to the company's ability to maintain valuable, rare, and indispensable resource assets and allocate and disseminate such resources effectively (Barney, 1991). With a sustained competitive advantage, the company that owns it will be able to win the competition in the market so that it can later create value and achieve the optimal performance of the company.

Some previous research examining the relationship between IC and company performance using VAIC proxies succeeded in finding the relationship between IC and company performance. Chen et al. (2005) found that IC owned companies were positively influential in the market value and financial performance of the company and could be an indicator of future financial performance. Meanwhile, Clarke et al. (2011) also show that there is a direct link between the IC and the performance of companies listed on the Australian Stock Exchange. Several other studies have also managed to find evidence that IC has a positive relationship with the company's performance (Pratama and Wibowo, 2017; Pratama, 2016; Tan et al., 2007; Firer and Stainbank, 2003). Based on the explanation above, the hypothesis presented in this study is as follows:

H1: Intellectual Capital positively affects current financial performance.

\section{2) Intellectual Capital and Future Company Performance}

The positive influence of intellectual capital not only highlights the company's current financial performance, but also future financial performance. Tan, et al. (2007) argues that if IC is the main driver of the value of the company, then logically IC is also correlated with future performance enhancement, not only in today's performance. Intellectual Capital Utilization will maximize the effectiveness and efficiency of the company. Investor confidence will be increasingly higher if the company continues to explore and exploit the IC as best as possible. The Company will continue to maintain and even improve its financial performance in the present and future so that investors will have confidence in the company not only at this time but also in the future (Astuti and Margasari, 2016). Previous research (Tan, et al., 2007; Astuti and Margasari, 2016; Nuraini, et al., 2018) succeeded in proving IC's influence on the company's future financial performance. Based on this explanation, the hypothesis presented in this study is as follows:

H2: Intellectual Capital positively affects future financial performance.

\section{3) Intellectual Capital Growth Rate and Current \& Future Company Performance}

Resource-based theory (RBT) explains that IC is the core of value creation and the company's competitive Edge (Barney, 1991). If IC is a major driver for the value of the company, then a company with a higher IC will tend to have a better future performance, then the logic, IC growth rate (ROGIC) will also have a positive effect on the company's future performance (Tan et al., 2007). In the study of Tan et al. (2007) proved that ROGIC has a positive influence on the company's future performance. Based on the explanation, the hypothesis presented in this study is as follows:

H3: ROGIC positively affects current and future financial performance.

\section{RESEARCH METHOD}

\section{Types and Data of Research}

The type of data used in this study is secondary data. This research uses data on the financial statements of manufacturing companies listed on the Indonesia Stock Exchange, Malaysia, Singapore, Thailand, and the Philippines. Financial report data is obtained from the official website of the Indonesia Stock Exchange, Malaysia, Singapore, Thailand, and the Philippines or directly from the respective company's website. The year of observation in this study began from 2015 to 2018 . The year was chosen because the year 2015 was the year in which the ASEAN Economic Community (MEA) came into effect.

\section{Research Samples}

The samples in this study are companies that belong to industries that are engaged in industries that include manufacturing industries in the Indonesia Stock Exchange, Malaysia, Singapore, Thailand, and the Philippines. 
The manufacturing industry is chosen because it is an industry that relies on IC for its corporate activities and innovations. This is in line with the opinions of Bontis (2001) and Hermans and Kauranen (2005) stating that the industry that has a lot of activity using IC is suitable and interesting to serve as IC research object.

\section{Variable Research}

\section{a. Independent Variables}

- Intellectual Capital (VAIC), as an independent variable. IC was measured using VAIC which was developed by Pulic (2000, 2004). Firer and Williams (2003) mentions the advantages of this VAIC method, among others, VAIC provides a consistent and standardized measurement that enables effective comparative analysis between companies and between countries; Data used in the VAIC calculations based on audited data in financial statements so that the calculations will be more objective. Besides, VAIC has also been widely used in research studies on IC (e.g., Clarke et al., 2011; Maditinos et al., 2011; Chan, 2009; Tan et al., 2007; Chen et al., 2005; Firer and Williams, 2003). VAIC is measured by the formula:

$$
V A I C_{t}=H C E_{t}+S C E_{t}+C E E_{t}
$$

Description:

\begin{tabular}{|c|c|}
\hline $\mathbf{V A I C}_{\mathbf{t}}$ & $\begin{array}{l}=\text { Value added } \\
\text { coefficient on } \mathrm{t}\end{array}$ \\
\hline $\mathrm{HCE}_{\mathrm{t}}$ & $\begin{array}{l}=\mathrm{VA}_{\mathrm{t}} / \mathrm{HC}_{\mathrm{t}} \text {; human capital } \\
\text { efficiency coefficient on } \mathrm{t}\end{array}$ \\
\hline $\mathbf{S C E}_{t}$ & $\begin{array}{l}=\mathrm{SC}_{\mathrm{t}} / \mathrm{VAt} \text {; structural capital } \\
\text { efficiency coefficient on } \mathrm{t}\end{array}$ \\
\hline $\mathrm{CEE}_{\mathrm{t}}$ & $\begin{array}{l}=\mathrm{VA}_{\mathrm{t}} / \mathrm{CE}_{\mathrm{t}} \text {; capital employed } \\
\text { efficiency coefficient on } \mathrm{t}\end{array}$ \\
\hline $\mathbf{V A} \mathbf{A}_{t}$ & $\begin{array}{l}=\mathrm{OUT}_{\mathrm{t}}-\mathrm{IN}_{\mathrm{t}}=\mathrm{OP}_{\mathrm{t}}+\mathrm{EC}_{\mathrm{t}}+\mathrm{D}_{\mathrm{t}} \\
+\mathrm{A}_{\mathrm{t}} ; \mathrm{VA} \text { Output (OUTt) } \\
\text { calculated from the total sales } \\
\text { minus the Input (INt) calculated } \\
\text { from the bought-in materials or } \\
\text { cost of goods or services sold; } \\
\text { Or can also calculation between } \\
\text { operating income }\left(\mathrm{OP}_{\mathrm{t}}\right) \text {; } \\
\text { employee costs }\left(\mathrm{EC}_{\mathrm{t}}\right) ; \\
\text { depreciation }\left(\mathrm{D}_{\mathrm{t}}\right) ; \quad \mathrm{dan} \\
\text { amortization }\left(\mathrm{A}_{\mathrm{t}}\right)\end{array}$ \\
\hline
\end{tabular}

$\mathbf{H C}_{\mathbf{t}}=$ Total salary and wages on $\mathrm{t}$
$\mathbf{S C}_{\mathbf{t}}=\mathrm{VA}_{\mathrm{t}}-\mathrm{HC}_{\mathrm{t}}$; structural capital on $\mathrm{t}$
$\mathbf{C E}_{\mathbf{t}}=$ book value of the net assets on $\mathrm{t}$

- Rate of Growth of Intellectual Capital (ROGIC), As independent variables. Rate of Growth of Intellectual Capital or IC growth rate is profiled with ROGIC which is measured using a formula that refers to the research of Tan, et al. (2007), as follows:

$$
R O G I C_{t}=\frac{V A I C_{t}-V A I C_{t-1}}{V A I C_{t-1}}
$$

\section{b. Dependent Variable}

- Enterprise Performance (Firm_Perf), as a dependent variable. As in Pratama research (2016) and Pratama and Wibowo (2017), the company's financial performance is measured using ROA (return on assets) which is calculated with the following formula:

ROA = Profit before tax / Average total assets.

\section{c. Control Variables}

- Enterprise Size (FSize), as a control variable. The company size is profiled by using total company assets in year $\mathrm{T}$, then in logarithmic.

- Leverage (Lev), as a control variable. Leverage is calculated by dividing longterm debt with total assets.

\section{Analytical Techniques}

According to Gujarati and Porter (2009), studies using the data panel should be tested with a regression model of data panels using-fixed effect regression or random effect regression. Therefore, this study uses the analysis of the model data regression panel, i.e. fixed effect regression or random effect regression by first performing a Hausman test to find out which panel data regression model is more appropriate.

The hypothesis testing in this study used two research models. The following is a model used to test three hypotheses in the study:

Model 1. Model of Independent Variable Effect Testing IC and IC Growth Against Dependent Variable Financial Performance of The Present 
ROA $_{t}=\beta_{0}+\beta_{1}$ VAIC $_{t}+\beta_{2}$ ROGIC $_{t}+\beta_{3}$ FSize $_{t}$

$$
+\beta_{4} L e v_{t}+\varepsilon_{t}
$$

Model 2. Model of Independent Variable Impact Testing IC and IC Growth Against Dependent Variables of Future Financial Performance ROA $_{t+1}=\beta_{0}+\beta_{1}$ VAIC $_{t}+\beta_{2}$ ROGIC $_{t}+\beta_{3}$ FSize $_{t}$

$$
+\beta_{4} \operatorname{Lev}_{t}+\varepsilon_{t}
$$

Description:

$\mathbf{R O A}_{\mathbf{t}}=$ Current financial performance

$\mathbf{R O A}_{\mathbf{t + 1}}=$ Future financial performance

VAIC $=$ Intellectual Capital

ROGIC $=$ Rate of growth of intellectual capital

FSize $=$ Enterprise Size Control Variables

Lev = Variable control leverage

$\varepsilon_{t} \quad=$ errorterm

\section{Conceptual Skeleton Model Research}

In general, the relationship between intellectual capital and ROGIC with the current and future performance of the company in this study can be described as below:

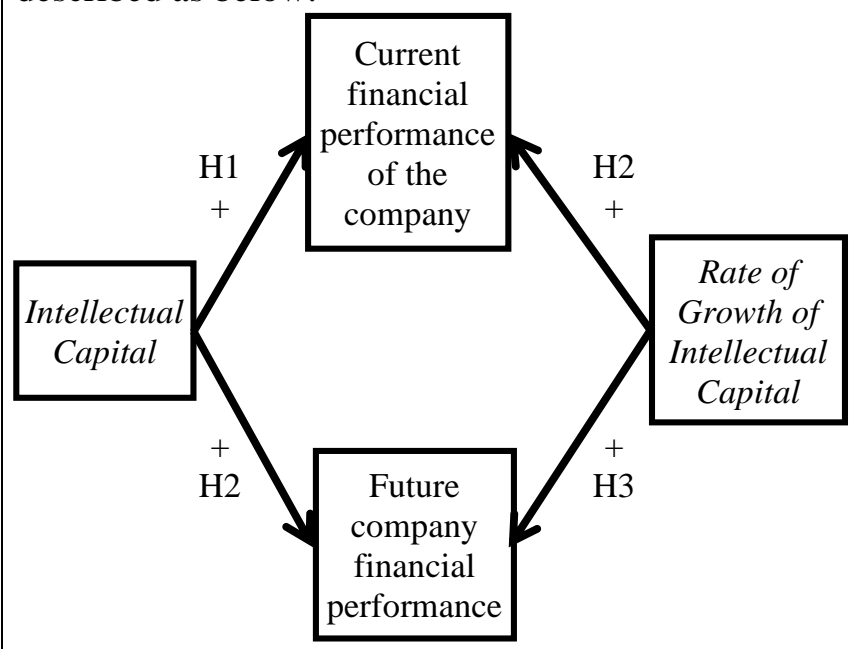

Pict 1. Conceptual framework Research

\section{RESULTS AND DISCUSSION}

\section{Descriptive statistics}

Table 3 shows the descriptive statistics of the variables selected in this study. ROAt has an average value of 7.230061 which indicates that the company has good enough profitability for the present period or in the same year. Meanwhile, ROAt +1 has an average value of 8.502558 which indicates that the company has enough good profitability for the future period or 1 year after $t$ year. Meanwhile, VAIC which is a proxy from intellectual capital Company has an average value of 4.26706. ROGIC or IC growth rate has an average value of 0.3085715 . Overall, the descriptive statistics of each variable can be seen in Table 3 below.

Table 1.

Descriptive statistical results

\begin{tabular}{lrrrr}
\hline Variable & Minimum & $\begin{array}{c}\text { Maximu } \\
\text { m }\end{array}$ & Mean & Std. Dev. \\
\hline ROA $_{\mathbf{t}}$ & 0.010 & 59.76 & 7.230061 & 6.173271 \\
ROA $_{\mathbf{t + 1}}$ & 0.040 & 47.95 & 8.502558 & 6.6948 \\
VAIC & 0.2245411 & 74.81979 & 4.26706 & 3.900305 \\
ROGIC & 0.0045734 & 0.9929932 & 0.3085715 & 0.237778 \\
FSize & 7.603598 & 17.58961 & 11.81314 & 1.642476 \\
Lev & 0 & 0.647884 & 0.0932813 & 0.1143237 \\
\hline
\end{tabular}

Hypothesis Testing Results

Table 2.

\begin{tabular}{|c|c|c|c|c|}
\hline \multirow{3}{*}{$\begin{array}{l}\text { Independent } \\
\text { Variables }\end{array}$} & \multirow{2}{*}{\multicolumn{2}{|c|}{$\begin{array}{c}\text { Model } 1 \\
\text { ROAt }\end{array}$}} & \multirow{2}{*}{\multicolumn{2}{|c|}{$\frac{\text { Model } 2}{\text { ROA }_{t+1}}$}} \\
\hline & & & & \\
\hline & Coeff. & $\mathbf{T}$ & Coeff. & $\mathbf{T}$ \\
\hline Const & 0.0119386 & 0.03 & -0.1117499 & -0.10 \\
\hline VAIC & 0.9491959 & $68.36^{* * *}$ & 0.9662814 & 9.14** \\
\hline ROGIC & 13.50362 & $75.25 * *$ & 16.11306 & $16.53 * *$ \\
\hline FSize & -0.0853254 & $-2.80 *$ & -0.0438495 & $\begin{array}{l}-0.43 \\
\end{array}$ \\
\hline Lev & 0.0962199 & 0.52 & 0.3977056 & 0.58 \\
\hline $\mathbf{R}^{2}$ Within & & 0.9907 & & 0.98863 \\
\hline $\mathbf{F}$ & & 59521.65 & & 1760.37 \\
\hline Prob > F & & 0.0000 & & 0.0000 \\
\hline \multicolumn{5}{|c|}{$\begin{array}{r}\text { Notes: ** indicates significance at the } 1 \% ; * \text { indicates } \\
\text { significance at the } 5 \%\end{array}$} \\
\hline
\end{tabular}

Hypothesis Testing Results

a. First Hypotheses Testing Results

The 1st hypothesis of the study aims to answer the question of whether there is a positive intellectual capital influence over the current financial performance. Table 4 shows the results of the hypotheses 1 test in this study on the outcome of model 1. The results showed that VAIC had a positive effect on ROAt as a proxy for today's financial performance with a coefficient of 0.9491959 at a significance of $\alpha=1 \%$. This suggests that if a company can use its IC more efficiently it can lead to an increase in the current financial performance or the same period as the IC investment. Therefore, the 1 hypothesis which stated that intellectual capital positively affects the current financial performance, is supported.

These results show that efficient and effective use of IC will lead the company to achieve a higher performance of the present day. This means that in the MEA era, companies must be more aware of the 
efficient and effective use of intellectual capital so that they can face the MEA challenge. It also shows that the use of IC more efficiently can lead to increased current financial performance or in the same period as the IC investment. The results of this study were consistent with previous research conducted by Chen et al. (2005), Clarke et al. (2011), Pratama and Wibowo (2017), Pratama (2018), and Pratama, et al. $(2019,2020)$ who found that intellectual capital has a positive effect on ROAt which is the company's present financial performance proxy. This results in the resource-based theory explaining that IC is a resource that is the core of value creation and a competitive advantage for the company (Barney, 1991). According to Chen et al. (2005) and Wang (2008), IC's sustained competitive advantage will enable the company to defeat competitors and also create added value, thereby contributing to the company's success.

\section{b. Second Hypotheses Testing Results}

The 2nd research hypothesis aims to answer the question of whether there is a positive influence on the intellectual capital of future financial performance. Table 4 shows the results of hypothesis 2 trials in this study on the Model 2 results. The results showed that VAIC had a positive effect on ROAt +1 as a future financial performance proxy with a coefficient of 0.9662814 at a significance of $\alpha$ $=1 \%$. This suggests that if a company can use its IC more efficiently it can lead to increased financial performance up to the future or in the $\mathrm{T}+1$ period or a period of 1 year after the IC investment. Therefore, the 2 hypothesis which stated that intellectual capital positively affects the financial performance in the future, is supported.

These results show that efficient and effective use of IC will lead the company to achieve higher performance, not only in the present but also in the future. Tan, et al. (2007) argues that if IC is the main driver of the value of the company, then logically IC is also correlated with future performance enhancement, not only in today's performance. Intellectual capital utilization will maximize the effectiveness and efficiency of the company. Investor confidence will be higher if the company continues to explore and exploit the IC as best as possible. The company will continue to maintain and even improve its financial performance in the present and future so that investors will have confidence in the company not only at this time but also in the future (Astuti and Margasari, 2016). The results of this study were consistent with previous research conducted by Tan, et al., (2007), Astuti and Margasari, (2016), and Nuraini, et al., (2018) who succeeded in proving IC's influence on the company's future financial performance.

\section{c. Third Hypotheses Test Results}

The 3rd hypothesis of the study aims to answer the question of whether there is a positive ROGIC influence or IC growth rate against current and future financial performance. Table 4 shows the results of the 3 hypothesis tests in this study on the results of models 1 and 2. The results showed that ROGIC as a proxy of IC growth rates had a positive effect on ROAt and ROAt +1 as a proxy for present and future financial performance with a coefficient of 13.50362 and 16.11306 at a significance rate of $\alpha=1 \%$. This indicates that the growth rate of IC firms that are increasingly high can lead to increased current financial performance up to the future or on $\mathrm{T}$ and $\mathrm{T}$ +1 periods or periods and 1 year after the doing of such IC investments. Therefore, hypothesis 3 which stated that ROGIC positively affects the current and future financial performance, is supported.

These results show the higher the growth rate of IC companies it will direct the company to achieve higher performance, not only in the present but also in the future. Resource-based theory (RBT) explains that IC is the core of value creation and the company's competitive Edge (Barney, 1991). If IC is a major driver for the value of the company, then the company that has the higher IC will be more likely to have a better future performance, then the logic, IC growth rate (ROGIC) will also have a positive effect on the company's future performance (Tan et al., 2007). The study of Tan et al. (2007) proved that ROGIC has a positive influence on the company's future performance.

\section{CONCLUSION}

This research examines the positive effects of IC and IC growth rates towards the present and future performance of companies operating in the manufacturing industry in ASEAN countries, namely Indonesia, Malaysia, Singapore, Thailand, and the Philippines. Empirical results show that intellectual capital positively affects current and future financial performance. This suggests that the use of efficient 
and effective intellectual capital will make the company achieve higher financial performance, not only in the present but also for the future. This implies that in the era of ASEAN economic community, companies must be more aware of the efficient and effective use of intellectual capital so that they can face the challenge.

The research also examines ROGIC's positive impacts towards current and future financial performance. Empirical results found that ROGIC had a positive impact on the company's financial performance, both in the present and in the future. ROGIC or IC growth rate proved to be helping the company to succeed in this competitive environment. Companies that allocate spending to invest higher IC growth get more benefits.

\section{REFERENCES}

Aramburu, N. dan J. Saenz. 2011. Structural capital, innovation capability, and size effect: an empirical study. Journal of Management \& Organization. Vol. 17 (3): 307-325.

Astuti, I. dan N. Margasari. 2016. Dynamic relationship between intellectual capital and Company's financial performance. ICEBESS 2016 Proceeding. International Conference on Ethics of Business, Economics, and Social Science: 91-103.

Barney, J. B. 1991. Firm resources and sustained competitive advantage. Journal of Management. Vol. 17 (1): 99-120.

Barney, J. B., D. Ketchen, dan M. Wright. 2011. The future of resource based theory: Revitalization or decline?. Journal of Management. Vol. 37 (5): 1299-1315.

Bontis, N. 1998. Intellectual capital: an exploratory study that develops measures and models. Management Decision. Vol. 36 (2): 63-76.

Bontis, N. 1996. There's a price on your head: managing intellectual capital strategically. Business Quarterly. Vol. 60 (4): 40-47.

Bontis, N. 2001. Assessing knowledge assets: a review of the models used to measure intellectual capital. International Journal of Management Review. Vol. 3 (1): 41-60.

Cabello-Medina, C., A. Lopez-Cabrales, dan R. Valle-Cabrera. 2011. Leveraging the innovative performance of human capital through HRM and social capital in Spanish firms. International
Journal of Human Resource Management. Vol. 22 (4): 807-828.

Campbell, B. A., R. Coff, dan D. Kryscynski. 2012. Rethinking sustained competitive advantage from human capital. The Academy of Management Review. Vol. 37 (3): 376-395.

Carmeli, A. dan B. Azeroual. 2009. How relational capital and knowledge combination capability enhance the performance of work units in a high technology industry. Strategic Entrepreneurship Journal. Vol. 3 (1): 85-103.

Chan, K. H. 2009. Impact of intellectual capital on organisational performance: An empirical study of companies in the Hang Seng Index (Part 1). The Learning Organization. Vol. 16 (1): 4-21.

Chan, K. H. 2009. Impact of intellectual capital on organisational performance: An empirical study of companies in the Hang Seng Index (Part 2). The Learning Organization. Vol. 16 (1): 22-39.

Chen, M. C., S. J. Cheng, dan Y. Hwang. 2005. An empirical investigation of the relationship between intellectual capital and firms' market value and financial performance. Journal of Intellectual Capital. Vol. 6 (2): 159-176.

Clarke, M., D. Seng, dan R. H. Whiting. 2011. Intellectual capital and firm performance in Australia. Journal of Intellectual Capital. Vol. 12 (4): 505-530.

Cooper, M. J., H. Gulen, dan M. J. Schill. 2008. Asset Growth and the Cross-Section of Stock Returns. The Journal of Finance. Vol. 63 (4): 1609-1651.

Firer, S. dan L. Stainbank. 2003. Testing the relationship between intellectual capital and a company's performance: Evidence from South Africa. Meditari Accountancy Research. Vol. 11 (1): 25-44.

Firer, S. dan S. M. Williams. 2003. Intellectual capital and traditional measures of corporate performance. Journal of Intellectual Capital. Vol. 4 (3): 348-360.

Gleason, K. I. dan M. Klock. 2006. Intangible capital in the pharmaceutical and chemical industry. The Quarterly Review of Economics and Finance. Vol. 46: 300-314.

Gujarati, D. N. dan D. C. Porter. 2009. Basic Econometrics 5th edition. McGraw Hill/Irwin. New York, USA.

Hermans, R. dan I. Kauranen. 2005. Value creation potential of intellectual capital in biotechnology- 
empirical evidence from Finland. $R \& D$ Management. Vol. 35 (2): 171-185.

Kale, P., H. Singh dan H. Perlmutter. 2000. Learning and protection of proprietary assets in strategic alliances: building relational capital. Strategic Management Journal. Vol. 21 (3): 217-237.

Kinkel, S., G. Lay, dan J. Wengerl. 2005. Innovation: More than Research and Development. Bulletins of the Manufacturing Performance Survey. Vol. 33: 1-12.

Kong, E. dan M. Farrell. 2010. Knowledge and learning capabilities in non-profit organisations: a relational capital perspective. The International Journal of Learning. Vol. 17 (3): 97-116.

Kozlenkova, I. V., S. A. Samaha, dan R. W. Palmatier. 2014. Resource-based theory in marketing. Journal of the Academy of Marketing Science. Vol. 42 (1): 1-21.

Maditinos, D., D. Chatzoudes, C. Tsairidis, dan G. Theriou. 2011. The impact of intellectual capital on firms' market value and financial performance. Journal of Intellectual Capital. Vol. 12 (1): 132-151.

Nahapiet, J. dan S. Ghoshal. 1998. Social capital, intellectual capital, and the organizational advantage. Academy of Management Review. Vol 23 (2): 242-266.

Nuraini, E., R. Hayati, dan F. Yulandi. 2018. The influence of intellectual capital on financial performance in sharia banking companies. Advances in Social Science, Education and Humanities Research (ASSEHR). Vol. 186: 5861.

Peteraf, M. dan J. B. Barney. 2003. Unraveling the resource-based tangle. Managerial and Decision Economics. Vol. 24 (4): 309-323.

Pratama, B. C. 2016. The Impact of Intellectual Capital of Indonesian's High-Tech Company on Firm's Financial and Market Performance. International Journal of Academic Research in Accounting, Finance and Management Sciences. Vol. 6 (4): 73-81.

Pratama, B. C. dan H. Wibowo. 2017. Family Ownership and the Entrenchment Effect on
Intellectual Capital Utilization: A Study of HighTechnology Companies in Indonesia Dealing with the ASEAN Economic Community (AEC). Jurnal Akuntansi dan Investasi. Vol. 18 (2): 222230.

Pulic, A. 2000. VAIC: an accounting tool for IC management. International Journal of Technology Management. Vol. 20 (5-8): 702714.

Pulic, A. 2004. Intellectual capital - does it create or destroy value?. Measuring Business Excellence. Vol. 8 (1): 62-68.

Seleim, A., A. Ashour, dan N. Bontis. 2007. Human capital and organizational performance: a study of Egyptian software companies. Management Decision. Vol. 45 (4): 789-801.

Sukmadinata, N. S. 2009. Metode Penelitian Pendidikan. Remaja Rosdakarya. Bandung, Indonesia.

Sullivan Jr., P. H. dan P. H. Sullivan Sr. 2000. Valuing Intangible Companies, an Intellectual Capital Approach. Journal of Intellectual Capital. Vol. 1 (4): 328-340.

Tan, H. P., D. Plowman, dan P. Hancock. 2007. Intellectual Capital and Financial Returns of Companies. Journal of Intellectual Capital. Vol. 8 (1): 76-95.

Wang, J. C. 2008. Investigating market value and intellectual capital for S\&P 500. Journal of Intellectual Capital. Vol. 9 (4): 546-563.

Wang, C. H. 2011. The moderating role of power asymmetry on the relationships between alliance and innovative performance in the high-tech industry. Technological Forecasting \& Social Change. Vol. 78: 1268-1279.

Zangoueinezhad, A. dan A. Moshabaki. 2009. The role of structural capital on competitive intelligence. Industrial Management \& Data Systems. Vol. 109 (1-2): 262-280. 